Konseling Kelompok Rasional Emotif Perilaku Dalam Membantu Mengatasi Regulasi Emosi Siswa ...

Ifta Nur Farichah, Bakhrudin All Habsy, Dimas Heri Suroso

\title{
KONSELING KELOMPOK RASIONAL EMOTIF PERILAKU DALAM MEMBANTU MENGATASI REGULASI EMOSI SISWA SMP, EFEKTIFKAH?
}

\author{
Ifta Nur Farichah \\ Bakhrudin All Habsy \\ Dimas Heri Suroso \\ Universitas Darul Ulum Jombang, \\ E-mail : iftafarichah@gmail.com
}

\begin{abstract}
Abstrak
Penelitian ini bertujuan untuk menguji keefektifan konseling kelompok Rasional Emotif Perilaku untuk meningkatkan regulasi emosi siswa SMP. Penelitian ini, menggunakan rancangan eksperimen dengan desain Nonequivalent Control Grup Design yang kemudian dianalisis dengan menggunakan uji statistik nonparametric. Berdasakan hasil analisis data diperoleh nilai z hitung -2,707 dan angka probabilitas (sig.(2tailed)) adalah 0,007. Selanjutnya angka tersebut dibandingkan dengan $\mathrm{z}$ tabel pada taraf signifikan 0,05 sehingga diketahui sebesar 1,96. Karena $\mathrm{z}$ hitung lebih kecil dari z tabel, dapat disimpulkan bahwa, konseling kelompok Rasional Emotif Perilaku efektif untuk meningkatkan regulasi emosi siswa SMP.
\end{abstract}

Kata kunci: Regulasi Emosi, Konseling Kelompok Rasional Emotif Perilaku

\begin{abstract}
This study aims to examine the effectiveness of Rational Emotive Behavior group counseling to improve emotional regulation of Junior High School students. In this research, a researcher used exsperiment structure whit design Nonequivalent Control Group Design which is then analyzed using a nonparametric statistical test. Based on the results of data analysis, the calculated $\mathrm{z}$ value is obtained -2.707 and the probability number (sig. (2-tailed)) is 0.007. Furthermore, the figure is compared with the $\mathrm{z}$ table at a significant level of 0.05 so that it is known as 1.96 , because $\mathrm{Z}$ count is wich smaller than $\mathrm{z}$ table. So it can be concluded that Rational Emotive Behavior group counseling is effective to improve emotional regulation of Junior High School students.
\end{abstract}

Keywords: Emotional Regulation, Rational Emotive Behavior Group Counseling

\section{PENDAHULUAN}

Sekolah Menengah Pertama yang selanjutnya disingkat SMP, adalah salah satu bentuk satuan pendidikan formal di Indonesia yang menyelenggarakan pendidikan formal sebagai bentuk pendidikan lanjutan dari SD atau MI atau bentuk lain yang sederajat (Nomor, 11 AD)

Pada saat individu memasuki tahapan pendidikan di sekolah menengah pertama, maka individu tersebut memasuki masa remaja yaitu masa peralihan dari masa kanak-kanak menuju masa dewasa, yang merupakan masa penuh gejolak dalam menghadapi banyak persoalan, tantangan, serta konflik dalam dirinya maupun pergaulannya. (B A Habsy, 2014)

Pernyataan tersebut dipertegas oleh Amett (Fitriani \& Alsa, 2015) yang menyatakan bahwa jika persoalan dan konflik pada diri remaja tidak teratasi dengan baik akan membawa pengaruh negatif dalam perkembangannya. Salah satu pengaruh negatif dalam perkembangan remaja adalah kemampuan remaja dalam mengembangkan dan mengontrol emosinya secara baik, dengan sifat sensitif dan reaktif yang sangat kuat terhadap berbagai situsi sosial.

Menurut Chaplin \& Aldao (2013) emosi adalah suatu keadaan individu dalam memahami perubahanperubahan diri yang mempengaruhi perubahan perilaku. Pernyataan tersebut dipertegas Damon dan Eisenberg yang menyebutkan emosi sebagai usaha individu untuk menentukan, mempertahankan, atau mengubah hubungan antara individu dengan lingkungan agar sesuai dengan keinginan individu dalam kelompoknya Emosi merupakan salah satu faktor psikologis yang berpengaruh pada perubahan 
tingkah laku remaja (Nisfiannoor \& Kartika, 2004). Menurut Kail, R. V., \& Nelson (1993) problematika yang terjadi pada remaja diantaranya adalah kontrol emosi yang rendah, kepercayaan beragama, kesehatan, ekonomi, serta problematika dalam pengelolaan waktu.

Pengaruh kemunculan emosi remaja dipengaruhi oleh lingkungan akademisi remaja seperti pada saat ujian, mengerjakan tugas yang melebihi batas kemampuan, kegiatan belajar yang membosankan karena guru kurang memiliki keterampilan dalam mengajar, mendapat komentar serta kirtik dari guru, atau umpan balik yang membuat individu merasa terkucilkan (Tyson, Linnenbrink-Garcia, \& Hill, 2009).

Menurut Garrison (Mappiare, 1984) kebahagian individu dalam menjalani kehidupan dipengaruhi oleh kemampuan memahami dan menguasi emosi. Pernyataan tersebut dapat ditafsirkan bahwa kemampuan mengendilakan emosi dalam diri dikenal sebagai regulasi emosi. Menurut Fridja (Salamah, 2012) regulasi emosi merupakan kemampuan individu untuk mengelola dan mengekspresikan perilakunya.

Menurut (Gross, 1998)regulasi emosi merupakan proses individu dalam menguasai emosi dalam dirinya, kapan individu merasakannya, dan bagaimana individu mengalami dan mengekspresikan emosi tersebut. Pernyataan tersebut dipertegas oleh Gross (Kurniasih \& Pratisti, 2013) proses regulasi emosi merupakan suatu cara dan strategi dalam menurunkan dan meningkatkan emosi. Menurut (Thompson, 1994) regulasi emosi merupakan kemampuan mengontrol emosi dan perilaku sebagai cara mengekspresikan emosi yang sesuai dengan lingkungan sekitarnya.

(Goleman, 2017) karakteristik individu yang memiliki kemampuan regulasi emosi tinggi terdiri dari enam aspek yaitu: (1) Kendali diri, yaitu mampu mengelola emosi dan impuls yang merusak dengan efektif, (2) Memiliki hubungan interpersonal yang baik dengan orang lain, (3) Memiliki sifat hati-hati, (4) Memiliki adaptibilitas, yang artinya luwes dalam menangani perubahan dan tantangan, (5) Toleransi yang lebih tinggi, serta (6) Memiliki pandangan yang positif terhadap diri dan lingkungannya.

(Gross, 1998) regulasi mempunyai lima aspek yang berperan penting dalam proses pembentukan perilaku yang ditampakkan. Lima aspek tersebut antara lain: (1) penilaian emosi (situation selection), (2) usaha-usaha yang dilakukan dalam rangka merubah dampak emosi yang ditimbulkan dari situasi tertentu (situation modification), (3) cara individu mengarahkan perhatiannya terhadap situasi tertentu dalam rangka mempengaruhi emosi yang dirasakan (attentional deployment), (4) perubahan makna dari situasi tertentu yang dapat menimbulkan dampak emosional (cognitive change), (5) respon secara psikis atau perilaku terhadap emosi tertentu yang muncul (response modulation).
Berdasarkan kajian teori tentang regulasi emosi yang telah dipaprkan dapat disimpulkan bahwa, pertumbuhan dan perkembangan remaja dalam masa transisi dari anak-anak ke fase remaja memunculkan masalah yang bersumber pada regulasi emosinya. Remaja dengan Karakteristik regulasi emosi rendah diantaranya, memiliki permasalahan dengan teman sebaya disekitar lingkungan mereka. Karakteristik remaja dengan regulasi emosi rendah cenderung bertindak tidak sesuai norma yang ada, misalnya menjadi pelaku bullying antar teman, pesimis, tidak percaya diri, mudah menyalahkan orang lain, meluapkan emosinya dengan hal-hal negatif, berkelahi dengan teman, dendam, pasrah, mudah marah dan putus asa. Sedangkan, karakteristik remaja dengan regulasi emosi tinggi diantaranya akan bertindak positif dan berkembang dengan baik dalam menjalankan kehidupanya. Pernyataan tersebut mempresentasikan gagasan (B A Habsy, 2014) tentang proses pencarian identitas diri tidak dapat terpisahkan dari regulasi emosi, karena regulasi emosi merupakan kebutuhan dasar setiap individu.

Regulasi emosi dalam penelitian ini adalah kemampuan individu untuk bisa mengembangkan dan mengontrol emosi secara teratur, dengan melakukan hal-hal yang positif dalam hidupnya, mampu meningkatkan emosi positif dan menurunkan emosi negatif. Regulasi emosi dalam penelitian ini diukur dengan angket yang berpedoman pada teori (Gross, 1998) yang terdiri dari dua aspek, yaitu: cognitive reappraisal dan expressive suppression.

Berdasarkan hasil studi pendahuluan di SMP Negeri 2 MGLH, sering menjumpai siswa dan siswi bermasalah yang berawal dari regulasi emosi yang masih belum stabil. Problematika tersebut memotivasi penulis untuk memberikan layanan dalam peningkatan regulasi emosi siswa tersebut dengan menggunakan layanan konseling. (B A Habsy, 2014) konseling dalam lingkup pendidikan merupakan upaya penanganan masalah dalam rangka memfasilitasi perkembangan individu dalam lingkungannya yang tertuju pada upaya menciptakan kondisi optimum bagi perkembangan individu.

Pendekatan konseling yang dipilih untuk meningkatkan regulasi emosi dalam penelitian ini adalah pendekatan konseling Rasional Emotif Perilaku. Konseling Rasional Emotif Perilaku didasarkan pada asumsi bahwa Manusia pada dasarnya adalah unik yang memiliki kecenderungan untuk berpikir rasional dan irasional (B A Habsy, 2014)

Sebuah penelitian yang dilakukan (Fitriani \& Alsa, 2015) di SMP di daerah Yogyakarta menunjukkan adanya sebuah keefektifan Relaksasi Autogenik dalam Meningkatkan Regulasi Emosi. Selanjutnya menurut (Syahadat, 2013) menegaskan bahwa pelatihan regulasi emosi dengan mengatur dan 
Konseling Kelompok Rasional Emotif Perilaku Dalam Membantu Mengatasi Regulasi Emosi Siswa... Ifta Nur Farichah, Bakhrudin All Habsy, Dimas Heri Suroso

mengendalikan emosi efektif untuk menurunkan perilaku agresif pada anak. Selanjutnya hasil penelitian (Ariningsun, 2014) menegaskan bahwa penerapan konseling kelompok rasional emotif perilaku mempunyai efek yang positif untuk meningkatkan pengendalian diri siswa SMP. Lebih lanjut (Maulida, n.d.) menegaskan bahwa bimbingan konseling rational emotive behavioral therapy islami efektif dalam meningkatkan regulasi diri siswa MTs. (Bakhrudin All Habsy, 2018) menegaskan bahwa konseling rational emotive behavioral dalam setting kelompok merupakan treatment yang efektif dan efisien dalam meningkatkan harga diri Siswa SMA.

Berdasarkan pemaparan hasil penelitian yang relevan di atas, dapat disimpulkan bahwa Konseling Rasional Emotif Perilaku merupakan intervensi yang aplikatif untuk mengatasi permasalahan-permasalahan psikologis. Konseling Rasional Emotif Perilaku dalam penelitian ini adalah sebuah pendekatan konseling yang menitik beratkan pada emosi, perilaku dan pola pikir (Bakhrudin All Habsy, 2018) Konseling Rasional Emotif Perilaku merupakan upaya bantuan kepada siswa dalam memecahkan masalah yang memfokuskan pada upaya untuk mengubah keyakinan konseli yang irasional menjadi rasional. Sehingga dapat mengurangi gangguan emosi serta memodifikasi keyakinan irasional menjadi keyakinan yang logis agar konseli dapat mengembangkan dirinya secara optimal (B A Habsy, 2014) Konseling Rasional Emotif Perilaku dalam penelitian ini terdiri dari tiga tahap, yaitu: tahap initial stage atau tahap awal, working atau tahap kerja, final stage. Tahap-tahap Konseling Rasional Emotif Perilaku divisualkan pada gambar berikut:

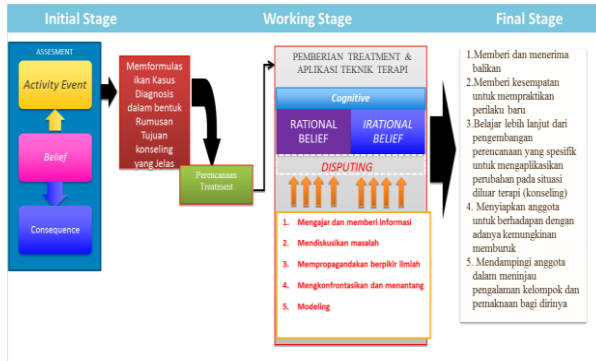

Gambar 1. Tahap-Tahap Konseling Rasional Emotif Perilaku

Berdasarkan latar belakang dalam penelitian ini maka rumusan masalah adalah Apakah Konseling Rasional Emotif Perilaku Efektif untuk Meningkatkan Regulasi Emosi Siswa SMP?

\section{METODE}

\section{Jenis Penelitian}

Jenis penelitian yang digunakan peneliti dalam penelitian ini adalah penelitian kuantitatif. Desain penelitian ini menggunakan desain eksperimen murni. Desain atau rancangan penelitian merupakan suatu proses yang diperlukan dalam perencanaan dan pelaksanaan sebuah penelitian (Bakhrudin All Habsy, 2017) Desain dalam penelitian ini divisualisasikan sebagai berikut:

\begin{tabular}{llll}
$\mathrm{R}_{1}$ & $O_{1}$ & $\mathrm{X}$ & $O_{2}$ \\
\hline $\mathrm{R}_{1}$ & $O_{3}$ & \multicolumn{2}{c}{$O_{4}$}
\end{tabular}

Keterangan:

$\mathrm{R}_{1}$ : Kelompok eksperimen

$\mathrm{R}_{2}$ : Kelompok kontrol

$O_{1}$ : Pre test kelompok eksperimen

$\mathrm{O}_{2}$ : Post test kelompok eksperimen

$X$ : Perlakuan konseling kelopok Rasional Emotif Perilaku untuk kelompok eksperimen

$\mathrm{O}_{3}$ : Pre test kelompok kontrol

$\mathrm{O}_{4}:$ Pre test kelompok kontrol

Untuk memperjelas rancangan penelitian eksperimen dalam penelitian ini, disajikan langkahlangkah sebagai berikut:

a. Melakukan pretest dengan menggunakan angket regulasi emosi kepada subjek penelitian sebelum diberikan perlakuan berupa konseling kelompok Rasional Emotif Perilaku

b. Membagi kelompok menjadi dua bagian, yaitu kelompok eksperimen dan kelompok kontrol. Pada kelompok eksperimen diberikan treatment berupa konseling kelompok konseling Rasional Emotif Perilaku sedangkan kelompok kontrol diberikan konseling kelompok tanpa teknik, yang keduanya dilakukan peneliti sebanyak 4 kali pertemuan.

c. Melakukan posttest pada kedua kelompok eksperimen dan kelompok kontrol. Hal ini dengan membandingkan tingkat regulasi emosi pada siswa sebelum dan setelah diberikan treatment. Posttest dilakukan pada akhir kegiatan setelah 4 kali proses pertemuan konseling Rasional Emotif Perilaku

d. Analisis data statistik, dengan alat bantu program SPSS versi 20.00 for windows untuk mengetahui keefektifan konseling kelompok Rasional Emotif Perilaku untuk meningkatkan regulasi emosi pada siswa SMP.

Secara visual, kerangka kerja penelitian konseling kelompok Rational Emotive Behavior untuk meningkatkan regulasi emosi siswa SMP, diilustrasikan dalam gambar sebagai berikut : 


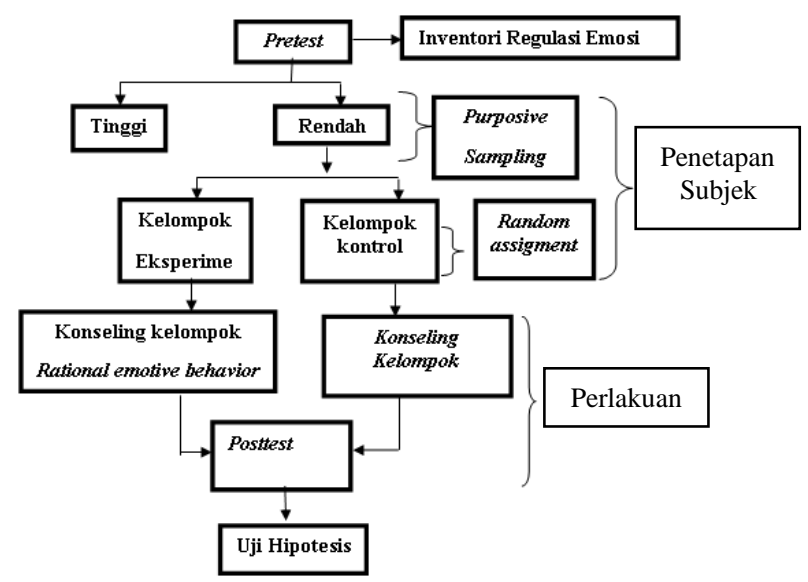

Gambar 2. Kerangka Kerja Penelitian

\section{Populasi dan Sampel Penelitian}

Populasi dalam penelitian ini, adalah siswa kelas 2 kelas SMPN 2 MGLH yang teridentifikasi memiliki regulasi emosi rendah. Berikut sajian populasi dalam penelitian ini pada tabel 1 .

Tabel 1. Jumlah Populasi Penelitian

\begin{tabular}{cccc}
\hline \multirow{2}{*}{ Kelas } & \multicolumn{2}{c}{ Jenis } & \\
& \multicolumn{2}{c}{ Kelamin } & Jumlah Siswa \\
\cline { 2 - 3 } & $\mathrm{L}$ & $\mathrm{P}$ & \\
\hline Kelas 2a & 15 & 14 & 29 \\
\hline Kelas 2b & 12 & 16 & 28 \\
\hline
\end{tabular}

Sampel dalam penelitian ini terdiri dari 12 orang yang teridentifikasi memiliki regulasi emosi rendah berdasarkan angket regulasi emosi dan dibagi menjadi 2 kelompok, yaitu kelompok eksperimen dan kelompok kontrol. Setiap kelompok terdiri dari 6 orang anggota. Sampel dalam penelitian ini termasuk sampling purposive (sampling bertujuan). Teknik pengambilan sampel dilakukan menggunakan teknik nonprobability sampling.

\section{Tempat dan Waktu}

Tempat Pelaksanaan penelitian dilaksanankan di SMPN 2 MGLH Jombang tahun ajaran 2018/2019.

Pelaksanaan untuk pemberian treatment konseling kelompok Rasional Emotif Perilaku berlangsung selama 3 bulan.

\section{Teknik Pengumpulan data}

Teknik Pengumpulan data dalam penelitian ini diungkap dengan menggunakan angket regulasi emosi berdasarkan (Gross, 1998) yang sudah diadaptasi dan diterjemahkan ulang melalui uji ahli keterbacaan, yang memiliki nilai validitas butir total dengan nilai $\mathrm{R}$ diatas 0,1796, dan reliabilitas sebesar 0,775. Adapun aspekaspeknya, yaitu: cognitive reppraisal dan expresive suppressioan. Dalam hal ini, penyusunan angket dilakukan peneliti dengan menggunakan skala likert. Skala likert dapat mengukur sikap individu dengan cara responden mengisi suatu pertanyaan atau pernyataan yang sesuai dengan dirinya.

\section{Analisis Data}

Data dalam penelitian ini dianalisis menggunakan statistik nonparametrik. (Santoso, 2014) statistik nonparametrik adalah statistik bebas sebaran (tidak mensyaratkan bentuk sebaran parameter populasi, baik normal atau tidak).

Metode analisis statistik nonparametrik yang digunakan dalam penelitian ini adalah uji dua sampel berpasangan (uji Wilcoxon). Uji wilcoxon digunakan untuk menganalisis hasil-hasil pengamatan yang berpasangan dari dua data, apakah terdapat titik perbedaan. Uji hipotesis, dalam penelitian ini terdiri dari dua kategori yaitu:

$\mathrm{H}_{0}: \mathrm{d}=0$ (tidak ada perbedaan diantara dua perlakuan yang diberikan)

Hi : $d \neq$ (ada perbedaan antara dua perlakuan yang diberikan)

Sedangkan dasar pengambilan keputusan dalam uji wilcoxon adalah sebagai berikut:

1. Dengan membandingkan angka $\mathrm{z}$ hitung dan $\mathrm{z}$ tabel:

Jika $\mathrm{z}$ hitung $<$ tabel, maka $\mathrm{H}_{0}$ diterima

Jika $\mathrm{z}$ hitung $>$ tabel, maka $\mathrm{H}_{0}$ ditolak

2. Dengan melihat angka probabilitas, dengan ketentuan:

Probabilitas $<0,05$ maka $\mathrm{H}_{0}$ diterima

Probabilitas > 0.05 maka $\mathrm{H}_{0}$ ditolak.

\section{HASIL DAN PEMBAHASAN}

Hasil Pre Test siswa yang tergolong rendah Kelompok Eksperimen dan Kontrol

Tabel 2. Hasil Pretest siswa yang tergolong rendah

\begin{tabular}{cccccc}
\hline NO & $\begin{array}{c}\text { Kelompok } \\
\text { kontrol }\end{array}$ & Skor & NO & $\begin{array}{c}\text { Kelompok } \\
\text { Eksperimen }\end{array}$ & Skor \\
\hline 1. & EM & 30 & 1. & MQA & 26 \\
2. & KIF & 28 & 2. & SDA & 16 \\
3. & RTA & 29 & 3. & NBPF & 15 \\
4. & TH & 30 & 4. & CCP & 25 \\
5. & AFN & 30 & 5. & WPE & 27 \\
6. & MRI & 28 & 6. & AB & 24 \\
\hline
\end{tabular}

Perolehan skor dan pembagian kelompok tersebut secara jelas digambarkan dalam diagram batang berikut ini : 


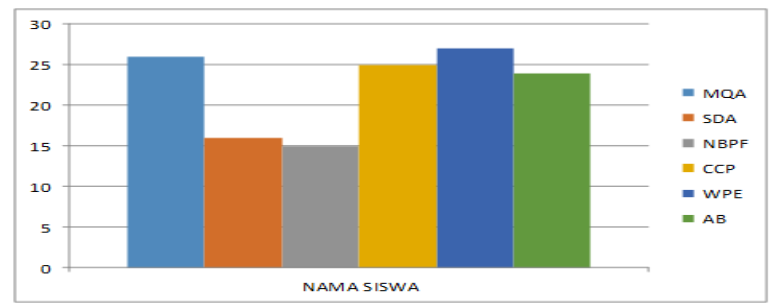

Gambar 3. Grafik Skor Pretest Kelompok Eksperimen

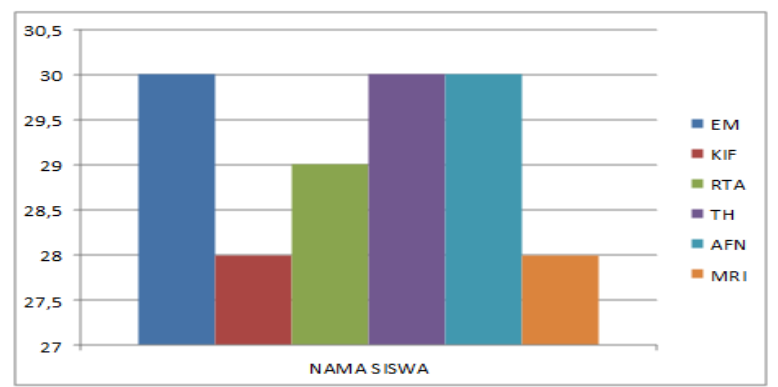

Gambar 4. Grafik Skor Pretest Kelompok Kontrol

Dalam penelitian ini, pelaksanan layanan konseling kelompok Rasional Emotif Perilaku, memfokuskan pada perubahan pemikiran irasional konseli menjadi pemikiran konseli, sehingga mempengaruhi peningkatan regulasi emosi.

Dalam implementasi konseling kelompok Rasional Emotif Perilaku, untuk meningkatkan regulasi emosi siswa SMP dilaksankan selama 4 kali pertemuan.

Pertemuan pertama, konselor melakukan perkenalan sekilas dengan konseli untuk menjalin hubungan baik dengan konseli Pada pertemuan pertama ini, konselor melaksanakan assessment yang meliputi (Activity event, beliefs, consequence). Konselor menggali beberapa informasi mengenai konseli yang berhubungan dengan emosi yang terjadi siswa di sekolah yang disesuaikan dengan aspek regulasi emosi dengan angket yang sudah disebarkan sebelumnya. Peneliti melaksanakan assessment sesuai dengan seberapa banyak data yang dibutuhkan konselor untuk melanjutkan ke tahap selanjutnya.

Pada pertemuan kedua dan ketiga konselor melakukan tahap working stage, dengan perumusan tujuan, dilakukan perecanaan dan perumusan treatment bersama dengan konseli serta menentukan teknik (Techique Implementation) yang akan digunakan oleh konselor dalam mencapai tujuan konseli. Selain itu, konselor juga memberikan homework pada semua anggota kelompok.

Konselor menerapkan konseling kelompok Rasional Emotif Perilaku untuk meningkatkan regulasi emosi remaja SMP. Konseling kelompok Rasional Emotif Perilaku menekankan pada perubahan belief sehingga mendapatkan pemikiran, emosi dan perilaku baru untuk menjadikan lebih baik.

Pada pertemuan keempat atau pertemuan terakhir, konselor melaksanakan evaluasi serta follow up terhadap konseling yang telah diberikan. Evaluasi konseling perilaku merupakan proses yang berkesinambungan. Evaluasi dibuat atas dasar apa yang konseli perbuat. Tingkah laku konseli digunakan sebagai tolak ukur untuk mengetahui keefektifan konseling yang sudah dilaksanakan.

Setelah kelompok eksperimen diberikan treatment berupa layanan konseling kelompok Rasional Emotif Perilaku, maka kedua kelompok (kelompok eksperimen dan kelompok kontrol) dikumpulkan kemudian diberikan Posttest. Hal ini bertujuan untuk membandingkan ada tidaknya perbedaan regulasi emosi siswa sebelum dan sesudah diberikan treatment layanan konseling kelompokRasional Emotif Perilaku. Selain itu, pemberian Posttest bertujuan untuk membedakan hasil antara kelompok eksperimen dan kelompok kontrol. Posttest dilakukan dengan memberikan inventori regulasi emosi siswa kepada kedua kelompok yang terdiri dari 10 item. Adapun hasil Posttest tersebut dapat dilihat dalam tabel 3 berikut ini:

Tabel 3. Hasil Post test Kelompok Ekperimen

\begin{tabular}{ccccc}
\hline NO & Nama & $\begin{array}{c}\text { Skor } \\
\text { Pretest }\end{array}$ & $\begin{array}{c}\text { Skor } \\
\text { Posttest }\end{array}$ & $\begin{array}{c}\text { Skor } \\
\text { perubahan }\end{array}$ \\
\hline 1. & MQA & 26 & 58 & 32 \\
2. & SDA & 16 & 47 & 31 \\
3. & NBPF & 15 & 31 & 16 \\
4. & CCP & 25 & 52 & 27 \\
5. & WPE & 27 & 35 & 8 \\
6. & AB & 24 & 36 & 12 \\
\hline
\end{tabular}

Dari tabel diatas maka hasil dari kelompok eksperimen pada saat pretest dan posttest dapat dilihat pada Grafik dibawah ini:

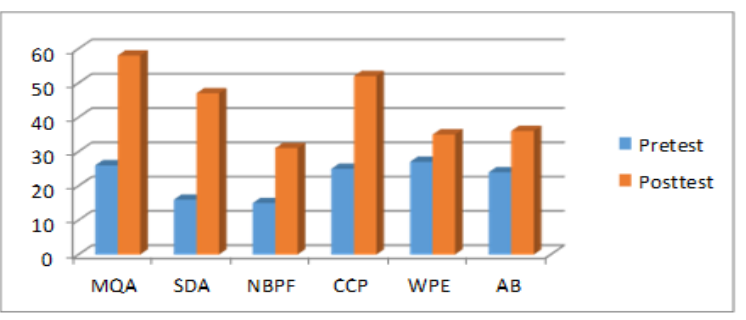

Gambar 5. Grafik Hasil Pretest dan Posttest Kelompok Ekperimen

Tabel 4. Hasil Post Test Kelompok Kontrol

\begin{tabular}{ccccc}
\hline No & Nama & $\begin{array}{c}\text { Skor } \\
\text { Pretest }\end{array}$ & $\begin{array}{c}\text { Skor } \\
\text { Posttest }\end{array}$ & $\begin{array}{c}\text { Skor } \\
\text { perubahan }\end{array}$ \\
\hline 1. & EM & 30 & 44 & 6 \\
\hline 2. & KIF & 28 & 30 & 2
\end{tabular}




\begin{tabular}{ccccc}
\hline No & Nama & $\begin{array}{c}\text { Skor } \\
\text { Pretest }\end{array}$ & $\begin{array}{c}\text { Skor } \\
\text { Posttest }\end{array}$ & $\begin{array}{c}\text { Skor } \\
\text { perubahan }\end{array}$ \\
\hline 3. & RTA & 29 & 38 & 9 \\
4. & TH & 30 & 34 & 4 \\
5. & AFN & 30 & 21 & -9 \\
6. & MRI & 28 & 49 & 21 \\
\hline
\end{tabular}

Dari tabel diatas maka hasil dari kelompok kontrol pada saat pretest dan posttest dapat dilihat pada Grafik dibawah ini.

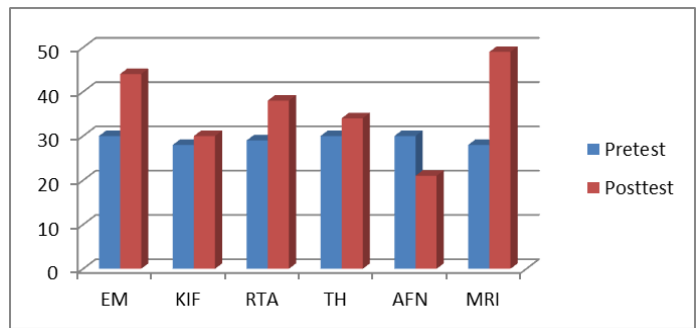

Gambar 6. Grafik Hasil Pretest dan Posttest kelompok Kontrol

Data hasil pretest dan posttest 12 siswa yang menjadi kelompok kontrol dan kelompok eksperimen selanjutnya dilakukan pengujian dengan menggunakan program spss 20 for windows dan hasil pengujian tersebut dapat diamati pada tabel dibawah ini:

Tabel 5. Hasil Uji Wilcoxon

\begin{tabular}{|c|c|c|c|c|}
\hline \multicolumn{5}{|c|}{ Ranks } \\
\hline & & $\mathrm{N}$ & Mean Rank & Sum of Ranks \\
\hline \multirow{4}{*}{ postest - pretest } & Negative Ranks & 1a & 4,50 & 4,50 \\
\hline & Positive Ranks & $11^{\mathrm{b}}$ & 6,68 & 73,50 \\
\hline & Ties & $0^{c}$ & & \\
\hline & Total & 12 & & \\
\hline \multicolumn{5}{|l|}{ a. postest < pretest } \\
\hline \multicolumn{5}{|l|}{ b. postest > pretest } \\
\hline \multicolumn{5}{|l|}{ c. postest $=$ pretest } \\
\hline
\end{tabular}

Berdasarkan tabel diatas, dapat dijelaskan bahwa pada negative ranks, salah satu anggota yang diketahui dari kelompok kontrol yang hasil posttestnya lebih rendah dari pada pretest. Kemudian pada positive ranks terdapat 11 siswa yang hasil posttestnya lebih tinggi dari pada pretestnya, disini diketahui bahwa ke-11 siswa tersebut terdiri dari 6 orang kelompok eksperimen yang telah diberi layanan konseling kelompok Rasional Emotif Perilaku dan 1 orang siswa dari kelompok kontrol yang tidak diberikan perlakuan berupa layanan konseling Rasional Emotif Perilaku. Selanjutnya pada test, terdapat 1 siswa dari kelompok kontrol yang memiliki hasil pretest dan posttest yang lebih rendah

Sedangkan dasar pengambilan keputusan dalam uji wilcoxon adalah sebagai berikut :

1. Dengan membandingkan angka $\mathrm{z}$ hitung dan $\mathrm{z}$ tabel :
Jika $\mathrm{z}$ hitung $>\mathrm{z}$ tabel, maka Ho diterima

Jika $\mathrm{z}$ hitung $<\mathrm{z}$ tabel, maka Ho ditolak

2. Dengan melihat angka Probabilitas, dengan ketentuan :

Probabilitas $>0,05$ maka Ho diterima

Probabilitas < 0,05 maka Ho ditolak

Untuk mengetahui hasil uji wilcoxon selanjutnya,

dapat dilihat dari tabel berikut ini:

Tabel 6. Uji Wilcoxon

Test Statistics $^{\mathrm{a}}$

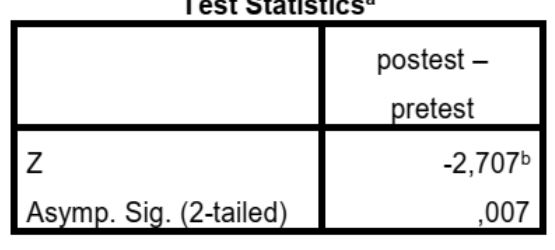

a. Wilcoxon Signed Ranks Test

b. Based on negative ranks.

Maka dapat dijelaskan bahwa, diketahui $\mathrm{z}$ hitung pada tabel diatas sebesar -2,707 dan angka probabilitas (sig.(2-tailed)) adalah 0,007. Selanjutnya angka tersebut dibandingkan dengan $\mathrm{z}$ tabel pada taraf signifikan 0,05 sehingga diketahui z tabel sebesar 1,96. Sesuai dengan dasar pengambilan keputusan dalam uji wilcoxon, karena $\mathrm{z}$ hitung diketahui sebesar $-2,707$ lebih kecil dari pada $\mathrm{z}$ tabel yang sebesar 1,96 dengan angka probabilitas yang didapat lebih kecil yakni 0,007 dari probabilitas yang sebesar 0,05, maka itu artinya terdapat perbedaan yang signifikan terhadap regulasi emosi sebelum dan sesudah diberikanya layanan konseling kelompok Rasional Emotif Perilaku. Dengan kata lain, konseling kelompok Rational Emotive Behavior efektif digunakan untuk meningkatkan regulasi emosi siswa di SMPN 2 MGLH.

Perubahan peningkatan regulasi emosi pada siswa kelompok eksperimen dan kelompok kontrol dilihat dari skor inventori pada saat pretest dan posttest. Dari hasil analisis statistik terlihat kelompok eksperimen dan kelompok kontrol mengalami peningkatan. Kelompok eksperimen yang diberikan perlakuan konseling kelompok Rasional Emotif Perilaku secara statistik lebih besar dari pada kelompok kontrol yang tidak diberikan konseling kelompok Rasional Emotif Perilaku.

Hasil penelitian ini mendukung hasil Penelitian sebelumnya yakni Konseling Rasional Emotif Perilaku lebih mempertimbangkan secara komprehensif dan integratif pada perasaan dan perilaku dibandingkan dengan terapi kognitif perilaku lainnya (Bakhrudin All Habsy, 2018) Konseling Rasional Emotif Perilaku memiliki penekanan yang kuat pada komponen emosional dan perilaku dan ditambah komponen kognitf (Sari, E. K. W., \& Soejanto, 2016) 
Konseling Kelompok Rasional Emotif Perilaku Dalam Membantu Mengatasi Regulasi Emosi Siswa... Ifta Nur Farichah, Bakhrudin All Habsy, Dimas Heri Suroso

Berdasarkan pemaparan penelitian diatas peneliti menggunakan konseling kelompok Rasional Emotif Perilaku yang dirancang untuk meningkatkan regulasi emosi siswa SMP yang dikategorikan sebagai masa remaja awal, (Kail, R. V., \& Nelson, 1993) mengemukakan bahwa masalah yang dihadapi remaja adalah masalah kontrol emosi, masalah dalam beragama, masalah kesehatan, masalah ekonomi, masalah pendidikan, serta masalah dalam mengisi waktu luang. Kail, R. V., \& Nelson (1993) juga berpendapat bahwa dalam mengatasi permasalahan setiap remaja berbeda-beda; ada yang mampu memecahkan masalahnya sendiri, namun ada pula remaja yang mengalami kesulitan (Fitriani \& Alsa, 2015)

Setelah memberikan intervensi menggunakan konseling kelompok Rasional Emotif Perilaku, siswa diberikan angket regulasi emosi untuk mengetahui tingkat tinggi dan rendahnya regulasi emosi siswa SMP. Hasil perhitungan skor regulasi emosi setelah diberikan intervensi menjadi lebih baik dari pada sebelum diberikan intervensi. Hasil skor rata-rata pada kelompok eksperimen setelah dilakukan intervensi adalah tinggi. Sedangkan skor rata-rata pretest pada kelompok kontrol dalam kategori rendah. Perhitungan skor Posttest regualasi emosi pada kelompok kontrol tidak berbeda jauh dari hasi pretest hal ini dikarenakan kelompok kontrol tanpa diberikan intervensi hasilnya sedikit meningkat meskipun tidak diberi intervensi.

Hasil penelitian ini menunjukan bahwa konseling kelompok Rasional Emotif Perilaku efektif untuk meningkatkan regulasi emosi siswa SMPN 2 MGLH. Dengan demikian Konseling kelompok Rasional Emotif Perilaku dapat dijadikan salah satu alternatif layanan konseling dalam upaya membantu siswa di sekolah khususnya untuk meningkatkan regulasi emosi.

Secara umum Konseling Kelompok Rasional Emotif Perilaku untuk meningkatkan regulasi emosi dapat berlangsung secara efektif jika dibandingkan dengan konseling kelompok tanpa teknik. Sehingga Konseling Kelompok Rasional Emotif Perilaku diharapkan dapat meningkatkan efisiensi kinerja para konselor yang jumlahnya sangat terbatas bila dibandingkan konseli yang ditangani.

Temuan dalam penelitian ini diharapkan sebagai acuan guru bimbingan dan konseling di sekolah dalam memberikan layanan konseling kelompok Rasional Emotif Perilaku dalam membantu siswa mengatasi permasalahannya.

Hasil kajian teori dan temuan penelitian ini menunjukan manfaat besar Konseling Kelompok Rasional Emotif Perilaku mengintervensi pada aspek kognitif dan emotif sehingga membawa perubahan pada aspek perilaku dan emosi sehingga dapat menjadi pertimbangan bagi para pendidik konselor untuk melatihkan Konseling Kelompok Rasional Emotif Perilaku terhadap para calon konselor.

Kelebihan utama penelitian ini adalah peneliti membandingkan dua kelompok yaitu kelompok eksperimen dan kelompok kontrol. Kelompok eksperimen mendapatkan intervensi konseling kelompok Rasional Emotif Perilaku dan konseling kelompok tanpa teknik (group counseling as usual) pada kelompok kontrol. Selain itu desain pretest and posttest control group design, yang digunakan dalam penelitian ini juga memiliki kekuatan dengan adanya pengukuran di awal dan akhir intervensi

Peneliti menyadari bahwa terdapat keterbatasan pada tolak ukur terjadinya peningkatan regulasi emosi, pengukuran regulasi emosi siswa hanya dilakukan dengan menggunakan inventori regulasi emosi yang dikembangkan oleh peneliti berdasarkan teori yang dikemukakan (Gross, 1998) yang terdiri dari dua aspek, yaitu: cognitive reappraisal dan expressive suppression. Namun banyak hal yang mempengaruhi psikologis manusia sehingga dibutuhkan tidak hanya sekedar pengkategorian dengan menggunakan instrumen saja.

Pengukuran regulasi emosi secara berulang di awal dan di akhir intervensi dengan menggunakan satu format inventori akan memunculkan ancaman validitas internal penelitian dari sisi testing. Untuk mengurangi ancaman tersebut, peneliti melakukan beberapa langkah-langkah untuk menjamin validitas internal penelitian yaitu dengan melakukan pengacakan item inventori regulasi emosi, peneliti memisah pretest dan posttest dengan jarak yang lama agar subjek penelitian dapat mengisi instrumen sesuai dengan keadaan dirinya.

Keterbatasan lain dalam penelitian ini adalah pelaksanaan Konseling Kelompok Rasional Emotif Perilaku hanya terbatas pada satu tempat saja, yaitu di SMPN MGLH, sehingga ada kemugkinan hasilnya akan berbeda saat dilakukan di tempat lain. Namun demikian, sekolah ini dapat mewakili Sekolah Menengah Pertama lain bahwa jika penelitian yang sama dilakukan di sekolah lain ada kemugkinan perbedaan hasil, namun kemugkinan hasilnya tidak akan berbeda jauh.

\section{PENUTUP \\ Simpulan}

Berdasarkan hasil analisis dan pembahasan terhadap penelitian yang dilakukan, maka dapat diambil kesimpulan bahwa konseling kelompok Rasional Emotif Perilaku efektif untuk meningkatkan regulasi emosi siswa SMPN 2 MGLH Tahun Pelajaran 2018/2019. Hal tersebut dapat diketahui dengan adanya peningkatan skor posttest konseli setelah diberikan treatment (konseling kelompok konseling kelompok 
Rasional Emotif Perilaku), peningkatan respon perilaku konseli.

\section{Saran}

Berdasarkan pada hasil penelitian dan kesimpulan hasil penelitian, diajukan beberapa saran sebagai berikut:

1. Bagi guru Bimbingan dan Konseling, jika menemukan permasalahan regulasi emosi rendah pada siswa maka dapat menggunakan konseling kelompok konseling kelompok Rasional Emotif Perilaku.

2. Bagi peneliti selanjutnya, penelitian ini dapat dijadikan bahan referensi dalam mengatasi permasalahan regulasi emosi rendah dengan menggunakan konseling kelompok konseling kelompok Rasional Emotif Perilaku.

\section{DAFTAR PUSTAKA}

Ariningsun, A. (2014). Penerapan Konseling Kelompok Rasional Emotif Perilaku Untuk Meningkatkan Pengendalian Diri Siswa Kelas VIII SMP Negeri 4 Panggul Trenggalek. Jurnal BK UNESA, 4(3).

Chaplin, T. M., \& Aldao, A. (2013). Gender differences in emotion expression in children: A meta-analytic review. Psychological Bulletin, 139(4), 735.

Fitriani, Y., \& Alsa, A. (2015). Relaksasi autogenik untuk meningkatkan regulasi emosi pada siswa SMP. Gadjah Mada Journal of Professional Psychology (GamaJPP), 1(3).

Goleman, D. (2017). What Makes a Leader?(Harvard Business Review Classics). Harvard Business Press.

Gross, J. J. (1998). The emerging field of emotion regulation: An integrative review. Review of General Psychology, 2(3), 271-299.

Habsy, B. A. (2014). Teori dan pendekatan konseling modern dan post modern. Jombang: Undar Press.

Habsy, B. A. (2017). Seni Memehami Penelitian Kuliatatif Dalam Bimbingan Dan Konseling: Studi Literatur. Jurnal Konseling Andi Matappa, 1(2), 90-100.

Habsy, B. A. (2018). Konseling rasional emotif perilaku: Sebuah tinjauan filosofis. Indonesian Journal of Educational Counseling, 2(1), 13-30.
Kail, R. V., \& Nelson, R. W. (1993). Development psychology.

Kurniasih, W., \& Pratisti, W. D. (2013). Regulasi emosi remaja yang diasuh secara otoriter oleh orangtuanya.

Mappiare, A. (1984). Pengantar Bimbingan dan Konseling di Sekolah. Surabaya: Usaha Nasional.

Maulida, I. D. (n.d.). EFEKTIVITAS BIMBINGAN KONSELING RATIONAL EMOTIVE BEHAVIORAL THERAPY ISLAMI UNTUK MENINGKATKAN REGULASI DIRI PESERTA DIDIK MTs MIFTAHUL ULUM LENTENG SUMENEP MADURA.

Nisfiannoor, M., \& Kartika, Y. (2004). Hubungan antara regulasi emosi dan penerimaan kelompok teman sebaya pada remaja. Jurnal Psikologi, 2(2), 160-178.

Nomor, P. P. (11AD). Tahun 2010. Tentang Cagar Budaya.

Salamah, A. (2012). Gambaran emosi dan regulasi emosi pada remaja yang memiliki saudara kandung penyandang autis.

Santoso, S. (2014). Statistik Multivariat Edisi Revisi. Jakarta: PT Elex Media Komputindo, 224.

Sari, E. K. W., \& Soejanto, L. T. (2016). Keefektifan Konseling Kelompok REBT untuk Meningkatkan Self Esteem Mahasiswa. JKI. Jurnal Konseling Indonesia. https://doi.org/101106

Syahadat, Y. M. (2013). Pelatihan regulasi emosi untuk menurunkan perilaku agresif pada anak. Humanitas: Jurnal Psikologi Indonesia, 10(1), 19-36.

Thompson, R. A. (1994). Emotion regulation: A theme in search of definition. Monographs of the Society for Research in Child Development, 59(2- 3), 25-52.

Tyson, D. F., Linnenbrink-Garcia, L., \& Hill, N. E. (2009). Regulating debilitating emotions in the context of performance: Achievement goal orientations, achievement-elicited emotions, and socialization contexts. Human Development, 52(6), 329-356. 